Hebrang Grgić, Ivana. (2014). Scholarly Journals at the Periphery:

the case of Croatia. Learned Publishing, 27 (1). pp. 15-20.

ISSN 0953-1513

doi $10.1087 / 20140103$ 


\title{
Scholarly Journals at the Periphery: the case of Croatia
}

(C) Ivana Hebrang Grgić 2014.

\begin{abstract}
:
We analyse 231 Croatian journals available on the national online platform (Hrčak portal).To qualify for analysis journals had to be peer reviewed and to have published at least one issue in 2012 There are some changes from the results of previous studies. More journals are internationally oriented and have variation in visits apparently depending on the scientific field. Publishers are still mostly not-for-profit but are more likely now to apply article processing/publication charges. This is new for Croatia and raises a question about its potential influence on the availability and visibility of scientific results. Results are relevant not only in Croatia but may also be representative of other countries at 'the periphery'.
\end{abstract}

\section{Introduction}

It is commonly accepted that journals and information flow are important parts of scientific development. ${ }^{1,2}$ One aim of the Open Access (defined in $2002^{3}$ ) movement is to improve access at a global level, although there is continuing debate about its success and publisher responses. ${ }^{4}$ In this paper, we focus on Croatian electronic scholarly journals and their editorial policies in order to find out how they fit in the global process of scholarly communication. 


\section{Main characteristics of peripheral scientific communities}

Scientific communication, and specifically Open Access, is somewhat different in socalled scientifically peripheral countries compared with the 'developed' world. Peripheral scientific communities are defined by either (or both) of two factors - language and economy. English is the "lingua franca" for the global scientific community. All the countries with official languages other than English (even if the languages have a long tradition); countries that do not have powerful publishing industry and/or countries that do not spend as much on research and scientific data acquisition can be considered as peripheral countries. ${ }^{5}$ Croatia, a new EU member (since July $1^{\text {st }} 2013$ ) is surely one of them - it has population of 4.5 million; its official language is Croatian and it is classified as a country with an emerging market and developing economy. ${ }^{6}$

Croatian journals and their publishers (as is the case with many journals and publishers from other "peripheral" countries) have several specific defining characteristics. Language is one of them. Trying to make their journals more visible in the global community, ${ }^{7}$ some editors decide to publish all or some articles in English. But there are scientific fields closely oriented to the Croatian language, culture or history; scientists from those fields need to write in Croatian. In all these scientific fields language deteriorates if not used. Therefore, efforts that are being made to raise impact by publishing in English sometimes can conflict with the interests of the national science and language (that can develop only by being used, for example by the adoption of new terminology). The same problem exists in any scientific community using a "rare" language, a problem which is recognised by some English speaking authors. ${ }^{8}$ 
Croatian scholarly journal publishers are non commercial (mostly non-for-profit organizations and institutions, funded by the state). They do not raise subscription prices; their main interest is not profit, but is mainly in the dissemination of research results. This is possible because they are co-funded by the Croatian Ministry of Science, Education and Sports (MSES) which is the main policy-making body and also controls the budget for science. Open Access through journals (the "golden route") is not a problem for Croatian publishers - most of them are willing to put their issues OA almost immediately after publication.

Local journals can have importance for the global scientific community, even if they are usually focused on local topics. Also local journals remain a mandatory component of local scientific infrastructure and policy. ${ }^{9}$

\section{Literature overview}

The earliest study of Croatian scholarly journals on the Internet showed that in 2002 there were 21 journals in Croatia that had full-text online versions of their printed issues. ${ }^{10}$ The number had increased to 44 by $2005 .{ }^{11}$ The launch of Hrčak, the portal of Croatian scientific journals, was very important for the further development of Croatian scholarly communication through online peer-reviewed journals. The idea originated in 2003 and was supported by the Croatian Library Association, the Croatian Information Technology Society and the Zagreb Archive Association. The project proposal was written in cooperation with Zagreb University Computer Centre (SRCE) and was financially supported by MSES. ${ }^{12}$ The portal was launched at the end of 2005, providing a simple and free interface for creating electronic journals. It also provides technical support, 
maintenance and data protection; it is OAI-PMH compliant and ensures long-term archiving. ${ }^{13}$ Chart 1 shows the growth of the portal till the end of $2013 .{ }^{14}$

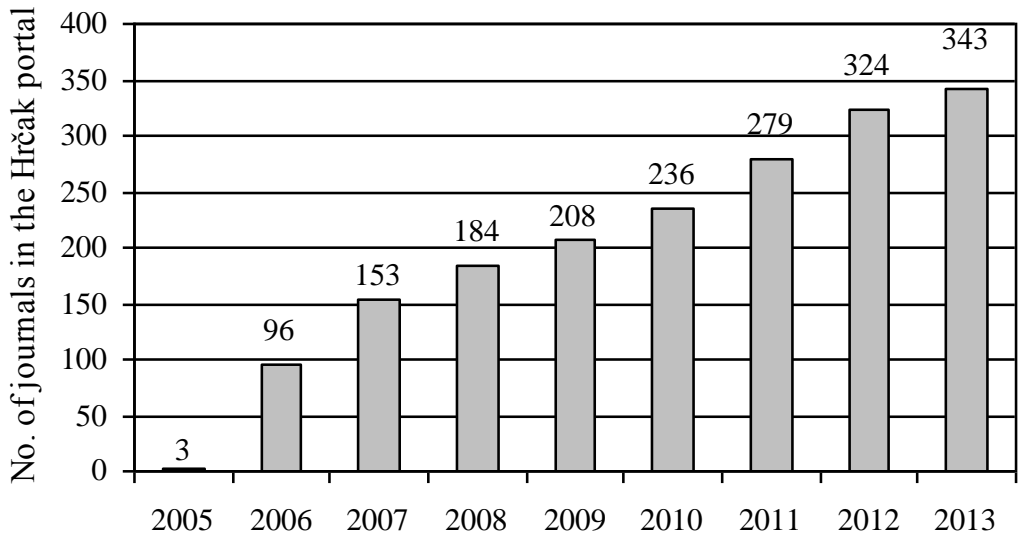

Because of the portal, Croatia has raised awareness of Open Access (OA) publishing and is well on the way to putting all of its journals OA. But Croatia still has problems with "green route" OA - for example the number of OA repositories is insufficient. Similar problems exist in other "peripheral" countries, as can be seen in statistics from OA databases (such as the Directory of Open Access Repositories, Directory of Open Access Journals or Registry of Open Access Repositories), but also from several reports (e. g. report on $\mathrm{OA}$ in southern European countries $^{5}$ or analysis of $\mathrm{OA}$ in the Czech Republic $\left.{ }^{15}\right)$.

In 2008 there were 125 Croatian journals with full text articles available on the Internet, 58 from the fields of Social Sciences and Humanities and 67 from the fields of Science, Technology and Medicine. ${ }^{16}$ Two publishers were profit organizations, all the others were not-for-profit and 70\% of journals published at least some articles in English. 
In a 2009 study of Croatian scholarly journals, 133 peer-reviewed journals with full-texts were identified on the Internet. Some of them were accessed via Hrčak portal and some of them via publishers' web sites. The study showed that all except three publishers, were not-for-profit, the majority of journals (70\%) published at least some articles in English and 18 journals from the sample were covered by Journal Citation Reports. ${ }^{17}$

Another study of Croatian journals focused on the field of social sciences in 2010. Based on 46 respondents, results of an online survey confirmed that changes in journal publishing in Croatia are similar to the changes at an international level. ${ }^{18}$

\section{Methodology, sample and hypotheses}

The sample for the research was based on the Hrčak, portal which covered 337 journals in June 2013. From the list, three groups of journals were excluded: journals that do not have full texts for at least one issue published in 2012; journals that promote popular science; and journals that publish only professional papers (i.e. papers that are not categorized as original scientific papers, review articles or preliminary communications). The final sample consisted of 231 journals that fulfil the two criteria:

1. they are scientific journals (i.e. publish categorised scientific articles based on peerreview process)

2. they have published at least one issue in 2012 with full-text articles by the end of June 2013

The main method is content analysis. Content of all the journals' websites on the Hrčak portal was analysed, and in some cases, publishers' websites had also to be consulted 
(some data about editorial boards are sometimes insufficient on Hrčak). For each journal we wanted to identify main characteristics of:

1. Publisher type - if for-profit, are the subscriptions high; if not-for -profit, which kind of organization - university, scientific institute, professional association or other? Publisher types will help us understand the differences or similarities between Croatian publishing practice and those in global scientific community. 2. Main scientific field of the journal - Although some journals are interdisciplinary, we decided to analyse them according to their main field, i.e. the field they choose to put in the first place in their journal description. In Croatian regulation there are six main scientific fields - natural sciences, technical sciences, biomedicine, biotechnology, social sciences and humanities. For this research, we group the journals in two main groups - one is science, technology and medicine (STM) and social sciences and humanities (SSH) is the other. We explored whether some aspects of editorial policies depend on specifics of different scientific fields.

3. Language of the articles published in the journal -. Some journals accept articles in either English or Croatian and some publish all the articles in both languages - has that changed compared to earlier studies and is the language connected to the scientific field? 4. Total number of issues and volumes available on Hrčak - Hrčak has existed for the last eight years but some publishers decide to make older issues and volumes available through the portal. That can increase visibility and impact of the journal but also helps preserve Croatian scientific and cultural heritage.

5. Editorial board (international or not) - how is the (inter)national editorial board connected with the language of the journal, its field and visibility? 
6. Usage of software for managing and publishing journals (e. g. Open Journal Systems, OJS) - how many journals use that kind of software, is it connected with the field, language or something else?

7. Is the journal cited in Journal Citation Reports (and if yes, what is impact factor)? Those data will also be compared to the scientific field and language, and the role of the database will be discussed.

8. How do the journals cover their publishing costs (besides being publicly funded)? How high are subscriptions (if they exist), how many journals charge APC (article processing charges) and what are they? Does the scale of charge relate to whether they are for-profit or non-profit?

9. Is there a difference in usage according to scientific field or language? The number of visits to journals is compared.

The research also aimed to compare present (2013) editorial practices to those in the past (2009 and 2010 studies). This enables us to explore trends and the possible influence of the changes for such a 'peripheral' country. Although the purpose of the two earlier studies was a little different, some parameters can be compared. Main conclusions of the past studies were:

- publishers of Croatian scientific journals are non-for profit organizations - authors do not have to pay for publishing in Croatian scientific journals

- subscriptions to printed versions are not high, even if the publisher is a for-profit organization (the highest subscription price was about 100 Euro per year)

- only a few journals publish articles in both English and Croatian 
- most journals publish at least abstract in a language other than Croatian (most usually in English)

- journals from the fields of social sciences and humanities are more likely to publish articles in Croatian

\section{Results and discussion}

Of the 231 journals, 98 are STM (42.4\%) and 133 are SSH (57.6\%).

Publishers of 225 journals are non-for-profit organizations - universities (102 or 44.2\%), professional associations (64 or $27.7 \%$ ) or scientific institutes (50 or $25.5 \%$ ). All the organizations are funded by the state. Six journals (2.6\%) are published by for-profit publishers. The number is not high, but it is higher than in 2009 survey (2 for-profit publishers). It is important to know that although the Croatian Ministry of Science, Education and Sports co-funds scientific journals, one of the criteria for the funding is that the publisher is non-for-profit organization. Croatian non-for-profit publishers and journal editors have to be careful. They may not be able to rely on the funding because of the global crisis and therefore it may fell safer to give the journal to a professional, forprofit publisher. But that could cause loss of public funding. Is it possible that Croatian for-profit publishers would try to make money from publishing Croatian scientific journals? At the moment, subscriptions to the six journals published by professional publishers are not high. We found three journals that charge the authors for publishing (or even submitting) their articles. That is not always clearly stated on the journals' web pages, and there is a possibility that some other journals do the same. One of the three journals has not started the practice yet, but it clearly says: "Submissions are free of 
charge during 2013", which suggest that that situation will change. Another journal asks the authors to pay 200 euro after their article is accepted. And the most expensive is the journal that charges 180 euro upon submission and another 420 euro upon acceptance. All the three journals publish in English so their potential authors are from the entire scientific community. It could be they chose to lose their local and national character, but then again they will probably have to face with the loss of national funding (which in any event is not very high because of the global economic crisis).

Subscription price details for 37 journals were found. Average price for individuals is 25 euro, and for institutions 34 euro. The prices are for printed copies. All the journals from the sample publish their full texts on the Hrčak portal, but some of them use an embargo period to sell printed copies.

Languages are usually Croatian and/or English. Some journals publish some articles in other languages and majority of journals publish abstracts in more than one language. In our analysis we had four categories of journals according to language. In the first category there are 93 journals (or 40.3\%) that publish all the articles in Croatian; in the second category are 69 journals (29.9\%) that publish all the articles in English; in the third category are 15 journals (6.5\%) that publish all the articles in both English and Croatian and in the fourth category are 54 journals (23.4\%) that publish the articles in either English or Croatian (or sometimes third language). Table 1 shows how are those categories correlated with scientific fields. The nature of social sciences and humanities is more "local" and national, so, not surprisingly, $61.6 \%$ of all SSH journals are published only in Croatian (82 journals). 41 journals with English articles (17.7\% of all journals) choose not to publish Croatian abstract, i. e. they publish articles and abstract in English. 
It is interesting again to see that 12 of them are $\mathrm{SSH}$ journals (9\% of all $\mathrm{SSH}$ journals) and 29 of them are STM journals (29.6\% of all STM journals). This shows again that the SSH journals, due to the nature of the fields, are more nationally oriented.

\begin{tabular}{|l|l|l|l|}
\hline language & STM & SSH & Total \\
\hline Croatian only & $11(11.22 \%)$ & $82(61.65 \%)$ & $93(40.26 \%)$ \\
\hline English only & $51(52.04 \%)$ & $18(13.53 \%)$ & $69(29.87 \%)$ \\
\hline Both English and Croatian & $6(6.12 \%)$ & $9(6.77 \%)$ & $15(6.49 \%)$ \\
\hline Either English or Croatian & $30(30.61 \%)$ & $24(18.05 \%)$ & $54(23.38 \%)$ \\
\hline total & 98 & 133 & 231 \\
\hline
\end{tabular}

Table 1. Language and scientific field of Croatian scholarly journals

Table 2 compares results with an earlier study (2009). It seems like more and more editors try to define their journals' orientation as national or international - there are more journals that publish articles only in one language (English or Croatian) and fewer journals that accept articles in either of the two languages.

\begin{tabular}{|l|l|l|}
\hline language & 2009 & 2013 \\
\hline Croatian & $30.40 \%$ & $40.30 \%$ \\
\hline English & $20.80 \%$ & $29.90 \%$ \\
\hline Both English and Croatian & $5.60 \%$ & $6.50 \%$ \\
\hline Either English or Croatian & $43.20 \%$ & $23.40 \%$ \\
\hline
\end{tabular}

Table 2. Percentage of journals publishing in Croatian and/or English in 2009 and 2013

Another element is the number of visits to journals. The average number of visits is 4270.5. For the SSH journals the average is higher (4808.1) than for STM journals (3874.4). Journals that publish articles in Croatian have on average 4812.7 visits, those that publish articles in English 3603.1 visits. We cannot tell where are the visitors from 
although it would seem likely that SSH journals are of more parochial interest. Although the Hrčak portal has existed for the last 8 years, some journals use it for publishing earlier issues. Average number of published volumes per journal is 11.6 and average number of issues per journal is 29 .

Some editors, editorial boards and publishers have implemented new technologies in the publishing process. 24 journals (or 10.4\%) use some kind of management and publishing system to automate the process (9 SSH journals and 15 SMT journals).

175 journals from the sample (75.8\%) have international editorial boards and 56 (24.2\%) national (Croatian) editorial boards. Out of 56 journals with national editorial boards, 36 publish articles only in Croatian. 35 journals with national editorial boards are from the fields of SSH. That is another demonstration of the national orientation of SSH journals. 38 journals (16.5\%) are in Journal Citation Reports (only 6 of those with national editorial boards and only 2 of those that publish only in Croatian). Croatian journals do not have high impact factors; average IF for 2012 is 0.430 . It is higher for STM journals (0.536) and is lower for SSH journals (0.268). That raises the question of adequacy of IFs, for peripheral scientific communities (the relatively new JCR practice of including more journals from peripheral countries is, of course, welcomed by them). Journals with international editorial boards and journals that publish at least some articles in English are more likely to be in the JCR database.

\section{Conclusion}

Croatia has a number of high quality scholarly journals that are globally recognized. Some scientific fields are more nationally oriented but, at the same time, important to 
global scientific community. Diversity of language and fields improves not only national science but also enhances global knowledge. Therefore, we believe that Croatian publishers should continue with their efforts in making their journals OA and in trying to avoid all the pitfalls that could lead to national access difficulties.

\section{References:}

1. Improving access to scientific information for developing countries: UK learned societies and journal access programmes. UNESCO. 2008. Available at: http://www.unesco.org.uk/uploads/Improving\%20Access\%20to\%20Scientific\%2 0Information\%20-\%20May\%2008.pdf (accessed 28 June 2013-07-2013).

2. Dalton, M. S. 2006. A system destabilized: scholarly books today. Journal of Scholarly Publishing 37: 251-69. http://dx.doi.org/10.1353/scp.2006.0012

3. Budapest Open Access Initiative. 2002. Available at http://www.soros.org/openaccess/read.shtml (accessed 28 June 2013).

4. Bjork, B. C. and Salomon, D. 2012. Pricing principles used by scholarly Open Access publishers. Learned publishing 25: 132-7. http://dx.doi.org/10.1087/20120207

5. Open Access in Southern European countries. Anglada, L., Abadal, E. (eds.). Madrid, FECYT, 2010. Available at: http://www.accesoabierto.net/sites/accesoabierto.net/files/OASouthEurope.pdf (accessed 28 June 2013).

6. World Economic Outlook Database. International Monetary Fund. April 2013. Available at: 
http://www.imf.org/external/pubs/ft/weo/2013/01/weodata/weoselco.aspx?g=220 $0 \& s g=$ All+countries $+\% 2 \mathrm{f}+$ Emerging + market+and+developing+economies (accessed 28 June 2013).

7. Bekavac, A. and Buneta, Z. 1993. Language barrier in a scientifically peripheral country: a case report from Croatia. Croatian Medical Journal 34: 272-5.

8. Garfield, E. 1990. The languages of science revisited: English (only) spoken here? Current Contents 31: 3-18.

9. Sambunjak, D.; Huic, M.; Hren, D.; Katic, M.; Marusic, A. and Marusic, M. 2009. National vs. international journals: views of medical professionals in Croatia. Learned Publishing 22: 57-70. http://dx.doi.org/10.1087/095315108X378785

10. Konjević, S. 2003. Hrvatski znanstveni časopisi na internetu [Croatian scientific journals online]. Vjesnik bibliotekara Hrvatske 46: 111-8. Available at: http://www.hkdrustvo.hr/datoteke/102/vbh/God.46(2003),br.3-4 (accessed 12 July 2013).

11. Hebrang Grgić, I. 2007. Bibliografska opremljenost i dostupnost članaka u hrvatskim znanstvenim časopisima [Bibliographic data and the accessibility of research papers in Croatian scientific journals]. Vjesnik bibliotekara Hrvatske 50: 79-88. Available at: http://www.hkdrustvo.hr/vbh/broj/95 (accessed 12 July 2013).

12. Toth, T. Centralni portal znanstvenih časopisa Hrvatske: Hrčak [Central portal of Croatian scientific journals: Hrčak]. Kemija u industriji. 33: 143-5. 
13. Stojanovski, J.; Petrak, J. and Macan, B. 2009. The Croatian national Open Access journal platform. Learned Publishing. 22: 263-73. http://dx.doi.org/10.1087/20090402

14. Visits by journals. Hrčak. 2013. Available at: http://hrcak.srce.hr/index.php?show=posjecenost-casopisa\&lang=en (accessed 15 June 2013).

15. Fabián, O. 2013. Open access in the Czech Republic: an overview. Library Review. 62: 211-23. http://dx.doi.org/10.1108/LR-09-2012-0096

16. Hebrang Grgić, I. Otvoreni pristup znanstvenim informacijama u hrvatskim znanstvenim časopisima i digitalnim repozitorijima [Open Access to scientific information in Croatian scientific journals and digital repositories] : $\mathrm{PhD}$ thesis, University of Zagreb, 2009.

17. Hebrang Grgić, I. Open Access to Scientific Information in Croatia: increasing research impact of a scientifically peripheral country. Saarbruecken, Lambert Academic Publishing, 2011.p 63. Available at: http://darhiv.ffzg.hr/1397/ (accessed 28 June 2013).

18. Vrana, R. 2011. A case of scientific journals in the field of social sciences in Croatia. Library Review. 60: 513-31. http://dx.doi.org/10.1108/00242531111147224

Ivana Hebrang Grgić, PhD, Department of Information and Communication Sciences, Faculty of Humanities and Social Sciences, University of Zagreb, I. Lucica 3, 10000 Zagreb, Croatia; email: ihgrgic@ffzg.hr 